\title{
Parameters for Simulation of Adult Subjects During Mechanical Ventilation
}

\author{
Jean-Michel Arnal MD, Aude Garnero MD, Mathieu Saoli, and \\ Robert L Chatburn MHHS RRT-NPS FAARC
}

\begin{abstract}
BACKGROUND: Simulation studies are often used to examine ventilator performance. However, there are no standards for selecting simulation parameters. This study collected data in passivelyventilated adult human subjects and summarized the results as a set of parameters that can be used for simulation studies of intubated, passive, adult subjects with normal lungs, COPD, or ARDS. METHODS: Consecutive adult patients admitted to the ICU were included if they were deeply sedated and mechanically ventilated for $<48 \mathrm{~h}$ without any spontaneous breathing activity. Subjects were classified as having normal lungs, COPD, or ARDS. Respiratory mechanics variables were collected once per subject. Static compliance was calculated as the ratio between tidal volume and driving pressure. Inspiratory resistance was measured by the least-squares fitting method. The expiratory time constant was estimated by the tidal volume/flow ratio. RESULTS: Of the 359 subjects included, 138 were classified as having normal lungs, 181 as ARDS, and 40 as COPD. Median (interquartile range) static compliance was significantly lower in ARDS subjects as compared with normal lung and COPD subjects $\left(39\right.$ [32-50] $\mathrm{mL} / \mathrm{cm} \mathrm{H}_{2} \mathrm{O}$ vs 54 [44-64] and 59 [43$75] \mathrm{mL} / \mathrm{cm} \mathrm{H}_{2} \mathrm{O}$, respectively, $\left.P<.001\right)$. Inspiratory resistance was significantly higher in COPD subjects as compared with normal lung and ARDS subjects $\left(22\right.$ [16-33] $\mathrm{cm} \mathrm{H}_{2} \mathrm{O} / \mathrm{L} / \mathrm{s}$ vs 13 [10-15] and $12[9-14] \mathrm{cm} \mathrm{H}_{2} \mathrm{O} / \mathrm{L} / \mathrm{s}$, respectively, $\left.P<.001\right)$. The expiratory time constant was significantly different for each lung condition $(0.60$ [0.51-0.71], 1.07 [0.68-2.14], and 0.46 [0.40-0.55] $\mathrm{s}$ for normal lung, COPD, and ARDS subjects, respectively, $P<.001)$. In the subgroup of subjects with ARDS, there were no significant differences in respiratory mechanics variables among mild, moderate, and severe ARDS. CONCLUSIONS: This study provides educators, researchers, and manufacturers with a standard set of practical parameters for simulating the respiratory system's mechanical properties in passive conditions. Key words: medical simulation; critical care; artificial respiration; respiratory mechanics; ARDS; COPD; lung compliance; airway resistance. [Respir Care 2018;63(2):158-168. (C) 2018 Daedalus Enterprises]
\end{abstract}

\section{Introduction}

Simulation studies are often used to examine ventilator performance because models of the respiratory system are

\footnotetext{
Dr Arnal, Dr Garnero, and Mr Saoli are affiliated with the Service de Réanimation Polyvalente, Hôpital Sainte Musse, Toulon, France. Dr Arnal is also affiliated with the Department of Medical Research, Hamilton Medical, Bonaduz, Switzerland. Mr Chatburn is affiliated with the Department of Medicine, Lerner College of Medicine and Respiratory Institute, Cleveland Clinic, Cleveland, Ohio.
}

Dr Arnal has disclosed a relationship with Hamilton Medical AG. Mr Chatburn has disclosed relationships with CareFusion, Covidien, Dräger, Hamilton, IngMar Medical, Inogen, Invacare, Philips, ResMed, Neotech, much easier to understand and experiment with than real respiratory systems (either human or animal). According to the Society for Simulation in Healthcare, "Simulation is

\footnotetext{
and Breathe Technologies. The other authors have disclosed no conflicts of interest.

Mr Saoli presented a version of this work at the Congrès Réanimation, held January 11-13, 2017, in Paris, France.

Correspondence: Jean-Michel Arnal MD, Service de Réanimation Polyvalente, Hôpital Sainte Musse, 54 Avenue Henri Sainte Claire Deville, 3056 Toulon, France. E-mail: jean-michel@arnal.org.
}

DOI: $10.4187 /$ respcare. 05775 
the imitation or representation of one act or system by another. Healthcare simulations can be said to have four main purposes-education, assessment, research, and health system integration in facilitating patient safety."1 Implicit in the concept of simulation is the understanding that the parameters of the simulation reflect realistic values of the system under study. If the model does not accurately represent the system being simulated, then any conclusions about the how the real system behaves are suspect. ${ }^{1}$ More importantly, models can be created that do not vary with time or with ventilator settings, so that the differences observed in measurements are presumed to be related only to performance differences among the ventilators in the study.

In the past, studies reporting ventilator performance ${ }^{2,3}$ often used some version of the Michigan Instruments Training and Test Lung simulator. This device has 1 or 2 springloaded bellows to model compliance (adjustable spring tension varies compliance values) connected in series with parabolic flow resistors. The Training and Test Lung is a passive device. To simulate inspiratory effort (muscle pressure $\left[\mathrm{P}_{\text {mus }}\right]$ in the equation of motion), researchers have improvised by linking the 2 bellows and using one to drive the other by connecting it to a separate ventilator. ${ }^{4}$ Thus, the larger the tidal volume and the higher the inspiratory flow of the drive ventilator, the higher the simulated inspiratory effort. Unfortunately, this procedure limits the shape of the $\mathrm{P}_{\text {mus }}(\mathrm{t})$ to the available flow shapes from the drive ventilator, which are quite limited. More recent studies $^{5-15}$ have used more sophisticated devices that allow high-fidelity simulation of both lung model (ie, resistance and compliance) and effort model ( $\mathrm{P}_{\text {mus }}$ waveform).

As suggested above, studies simulating the mechanical properties of the respiratory system are common. Unfortunately, although international standards for ventilator performance testing (for manufacturers) are available (https:// www.iso.org/standard/51141.html, Accessed July 29, 2017), there are no commonly accepted, clinically relevant standards for selecting simulation parameters that are evidencebased and linked to particular lung disease states (eg, normal, COPD, ARDS) or patient populations (eg, adult vs child vs infant). As a result, researchers typically pick values that seem reasonable to them, generally without regard to actual human data. This makes comparison of results among studies of ventilator performance difficult, and it makes meta-analysis impossible. Therefore, the purpose of this paper was to gather data on a large number of ventilated adult human subjects and to summarize the results as a set of parameters (grouped by lung disease) that can be used to construct standardized patients for simulation studies of intubated, passive patients (ie, all breaths are machine-triggered). In particular, we provide standardized values for respiratory system resistance and compliance that can be used in the equation of motion (either in

\section{QUICK LOOK}

\section{Current knowledge}

Although international standards for ventilator performance testing are available, there are no commonly accepted, clinically relevant standards for selecting simulation parameters that are evidence-based and linked to particular lung disease states.

\section{What this paper contributes to our knowledge}

This study provides educators, researchers, and manufacturers with standardized values for respiratory system resistance and compliance that can be used in the equation of motion (either in physical or mathematical models) for simulating the respiratory system's mechanical properties according to lung condition: normal; COPD; and mild, moderate, or severe ARDS.

physical or mathematical models). These values are grouped by lung condition: normal; COPD; and mild, moderate or severe ARDS.

\section{Methods}

This prospective, observational, comparative study was conducted from June 2015 to November 2016 in the 16bed general adult ICU of Sainte Musse Hospital in Toulon, France. The institutional review board approved the protocol, which was also declared at the Commission Nationale Informatique et Liberté. According to French regulation, signed consent was waived, and each patient's next of kin was informed by a document explaining the study and could refuse the patient's participation.

\section{Subjects}

Consecutive adult patients admitted in the ICU were included if they were deeply sedated (Richmond Agitation-Sedation Scale -4 or -5 ), were mechanically ventilated for $<48 \mathrm{~h}$ without any spontaneous breathing activity, and met criteria for a single lung condition (normal lungs, COPD, or ARDS). Patients were excluded in case of pregnancy, body mass index $>30 \mathrm{~kg} / \mathrm{m}^{2}$, severe hemodynamic impairment, bronchopleural fistula, brain death, or a mix of lung conditions (eg, COPD with ARDS). Sedation and myorelaxant were prescribed by the physician in charge of the subject, combining either midazolam or propofol with sufentanil, and cisatracurium were used. Subjects were positioned semirecumbently $\left(30-45^{\circ}\right)$ and mechanically ventilated using a Hamilton-S1 ventilator (Hamilton Medical, Rhäzüns, Switzerland). 


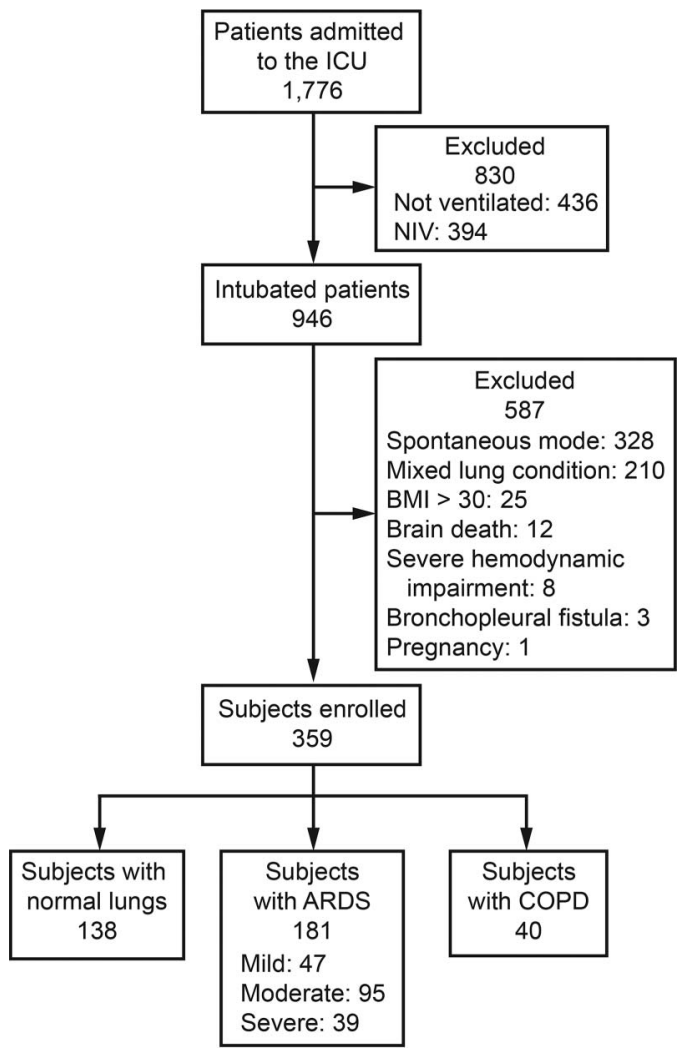

Fig. 1. Flow chart. NIV = noninvasive ventilation, $\mathrm{BMI}=$ body mass index.

A heat-and-moisture exchanger or a heated humidifier was used for gas conditioning.

Subjects were classified according to their lung condition as having normal lungs, COPD, or ARDS. Normal lungs was selected for subjects with no underlying respi- ratory disease, normal chest radiography on the inclusion day, and $\mathrm{P}_{\mathrm{aO}} / \mathrm{F}_{\mathrm{IO}_{2}}$ ratio of $\geq 300 \mathrm{~mm} \mathrm{Hg}$; ARDS was defined according to the Berlin definition with an arterial blood gas measured at a minimum of $5 \mathrm{~cm} \mathrm{H}_{2} \mathrm{O}$ of PEEP; 16 COPD was defined using Global Initiative for Chronic Obstructive Lung Disease criteria. ${ }^{17}$

\section{Ventilator Settings}

All subjects were ventilated with the mode called INTELLiVENT-ASV. ${ }^{18}$ Tidal volume $\left(\mathrm{V}_{\mathrm{T}}\right)$ was automatically controlled to be in the range of $5-8 \mathrm{~mL} / \mathrm{kg}$ predicted body weight for ARDS subjects, $6-9 \mathrm{~mL} / \mathrm{kg}$ predicted body weight for normal lung subjects, and $7-10 \mathrm{~mL} / \mathrm{kg}$ predicted body weight for COPD subjects. PEEP was automatically set in the range of $5-8 \mathrm{~cm} \mathrm{H}_{2} \mathrm{O}$ for normal lung subjects and 5-10 $\mathrm{cm} \mathrm{H}_{2} \mathrm{O}$ for $\mathrm{COPD}$ subjects, according to the PEEP- $\mathrm{F}_{\mathrm{IO}_{2}}$ table implemented in INTELLiVENT-ASV, which is derived from the ARDSnet tables. ${ }^{19}$ Plateau pressure was limited at $30 \mathrm{~cm} \mathrm{H}_{2} \mathrm{O}$ for all subjects.

\section{Measurements, Data Collection, and Calculations}

Airway pressure and flow were measured using the ventilator's proximal pneumotachograph (single-use flow sensor, PN 279331, Hamilton Medical, linear between -120 and $120 \mathrm{~L} / \mathrm{min}$ with a $\pm 5 \%$ error) inserted between the endotracheal tube and the Y-piece. When a heat-andmoisture exchanger was used, it was positioned distally to the sensor, so that measurements took into account the resistance of the heat-and-moisture exchanger. Volume was obtained by integration of the flow signal.

Table 1 Subject Characteristics at Inclusion

\begin{tabular}{|c|c|c|c|c|c|c|c|}
\hline \multirow{2}{*}{ Characteristics } & \multirow{2}{*}{ All Subjects } & \multirow{2}{*}{ Normal Lungs } & \multirow{2}{*}{ COPD } & \multicolumn{4}{|c|}{ ARDS } \\
\hline & & & & All & Mild & Moderate & Severe \\
\hline Number & 359 & 138 & 40 & 181 & 47 & 95 & 39 \\
\hline Male/female sex, $\%$ & $64 / 36$ & $68 / 32$ & $80 / 20$ & $60 / 40$ & $57 / 43$ & $60 / 40$ & $59 / 41$ \\
\hline Age, median (IQR) y & $67(56-76)$ & $65(52-73)$ & $66(61-75)$ & $68(57-78)$ & $68(60-80)$ & $69(56-78)$ & $67(57-78)$ \\
\hline BMI, median (IQR) kg/m² & $25(22-28)$ & $25(22-27)$ & $24(22-27)$ & $25(22-29)$ & $25(22-28)$ & $26(22-29)$ & $25(22-29)$ \\
\hline PBW, median (IQR) kg & $66(56-72)$ & $66(58-74)$ & $66(62-72)$ & $63(55-72)$ & $63(56-72)$ & $64(56-72)$ & $62(52-70)$ \\
\hline SAPS II, median (IQR) & $56(46-68)$ & $56(47-67)$ & $48(41-64)$ & $59(49-71)$ & $57(50-66)$ & $60(48-73)$ & $62(48-74)$ \\
\hline ETT size, median (IQR) mm & $7.5(7.5-8.0)$ & $7.5(7.5-8.0)$ & $7.5(7.5-8.0)$ & $7.5(7.5-8.0)$ & $7.5(7.5-8.0)$ & $7.5(7.5-8.0)$ & $7.5(7.5-8.0)$ \\
\hline Humidification, $\% \mathrm{HH} / \% \mathrm{HME}$ & $74 / 26$ & $53 / 47$ & $82 / 18$ & $88 / 12$ & $81 / 19$ & $86 / 14$ & $100 / 0$ \\
\hline Muscle relaxant, $n(\%)$ & $132(37)$ & $26(20)$ & $11(27)$ & $95(52)$ & $12(25)$ & $55(58)$ & $28(72)$ \\
\hline $\begin{array}{l}\mathrm{IQR}=\text { interquartile range } \\
\text { BMI = body mass index } \\
\text { PBW = predicted body weight } \\
\text { ETT = endotracheal tube } \\
\text { HH = heated humidifier } \\
\text { HME = heat-and-moisture exchanger }\end{array}$ & & & & & & & \\
\hline
\end{tabular}


Table 2 Ventilator Settings and Arterial Blood Gas Results

\begin{tabular}{|c|c|c|c|c|c|c|c|}
\hline \multirow{2}{*}{ Settings } & \multirow{2}{*}{$\begin{array}{l}\text { All Subjects } \\
(N=359)\end{array}$} & \multirow{2}{*}{$\begin{array}{l}\text { Normal Lungs } \\
\quad(n=138)\end{array}$} & \multirow{2}{*}{$\begin{array}{c}\text { COPD } \\
(n=40)\end{array}$} & \multicolumn{4}{|c|}{ ARDS } \\
\hline & & & & All $(n=181)$ & Mild $(n=47)$ & Moderate $(n=95)$ & Severe $(n=39)$ \\
\hline PEEP, $\mathrm{cm} \mathrm{H}_{2} \mathrm{O}$ & $8(5-12)$ & $5(5-7)$ & $7(5-10)$ & $12(9-15)$ & $10(7-12)$ & $12(9-15)$ & $12(10-16)$ \\
\hline $\mathrm{F}_{\mathrm{IO}_{2}}$ & $0.3(0.26-0.42)$ & $0.26(0.21-0.30)$ & $0.32(0.28-0.42)$ & $0.38(0.30-0.50)$ & $0.31(0.28-0.37)$ & $0.40(0.30-0.50)$ & $0.48(0.34-0.78)$ \\
\hline $\mathrm{V}_{\mathrm{T}}, \mathrm{mL} / \mathrm{kg} \mathrm{PBW}$ & $7.0(6.2-8.0)$ & $7.4(6.4-8.2)$ & $8.9(7.3-10.9)$ & $6.7(5.7-7.4)$ & $6.9(6.3-7.5)$ & $6.6(5.6-7.2)$ & $6.6(5.6-7.5)$ \\
\hline Frequency, breaths/min & $19(15-22)$ & $17(14-21)$ & $14(9-17)$ & $21(17-24)$ & $20(17-22)$ & $21(17-24)$ & $21(16-26)$ \\
\hline $\mathrm{P}_{\text {plat }}, \mathrm{cm} \mathrm{H}_{2} \mathrm{O}$ & $19(16-24)$ & $15(13-17)$ & $20(17-23)$ & $23(20-26)$ & $21(18-25)$ & $23(20-25)$ & $25(22-27)$ \\
\hline $\mathrm{pH}$ & $7.35(7.28-7.41)$ & $7.38(7.33-7.43)$ & $7.32(7.26-7.40)$ & $7.32(7.26-7.40)$ & $7.33(7.28-7.40)$ & $7.33(7.26-7.41)$ & $7.29(7.21-7.34)$ \\
\hline $\mathrm{P}_{\mathrm{aO}_{2}}, \mathrm{~mm} \mathrm{Hg}$ & $83(73-95)$ & $89(81-97)$ & $78(67-99)$ & $80(71-90)$ & $81(72-88)$ & $78(70-94)$ & $78(68-91)$ \\
\hline $\mathrm{P}_{\mathrm{aCO}_{2}}, \mathrm{~mm} \mathrm{Hg}$ & $40(37-47)$ & $37(35-39)$ & $51(45-55)$ & $43(38-50)$ & $39(37-46)$ & $43(39-50)$ & $49(44-56)$ \\
\hline $\mathrm{S}_{\mathrm{aO}_{2}}, \%$ & $96(94-98)$ & 97 (96-98) & 95 (93-98) & 95 (93-97) & $96(94-97)$ & 95 (94-97) & 94 (92-95) \\
\hline \multicolumn{8}{|c|}{$\begin{array}{l}\text { Results are median (interquartile range). } \\
\mathrm{V}_{\mathrm{T}}=\text { tidal volume } \\
\mathrm{PBW}=\text { predicted body weight }\end{array}$} \\
\hline
\end{tabular}

Table 3 Respiratory Mechanics Results for All Subjects

\begin{tabular}{|c|c|c|c|c|c|}
\hline Parameters & All Subjects $(N=359)$ & Normal Lungs $(n=138)$ & $\operatorname{COPD}(n=40)$ & $\operatorname{ARDS}(n=181)$ & $P$ \\
\hline $\mathrm{C}_{\mathrm{STAT}}, \mathrm{mL} / \mathrm{cm} \mathrm{H}_{2} \mathrm{O}$ & $47(38-58)$ & $54(44-64)$ & $59(43-75)$ & $39(32-50)$ & $<.001$ \\
\hline $\mathrm{R}_{\mathrm{INS}} \mathrm{LSF}, \mathrm{cm} \mathrm{H}_{2} \mathrm{O} / \mathrm{L} / \mathrm{s}$ & $12(10-16)$ & $13(10-15)$ & $22(16-33)$ & $12(9-14)$ & $<.001$ \\
\hline $\mathrm{RC}_{\mathrm{EXP}}, \mathrm{s}$ & $0.5(0.4-0.7)$ & $0.6(0.5-0.7)$ & $1.1(0.7-2.1)$ & $0.5(0.4-0.6)$ & $<.001$ \\
\hline $\mathrm{R}_{\mathrm{EXP}}, \mathrm{cm} \mathrm{H} \mathrm{H}_{2} \mathrm{O} / \mathrm{L} / \mathrm{s}$ & $13(11-15)$ & $12(10-14)$ & $18(14-36)$ & $14(11-16)$ & $<.001$ \\
\hline \multicolumn{6}{|c|}{$\begin{array}{l}\text { Results are median (interquartile range). } P \text { values are from analysis of variance. } \\
C_{\text {STAT }}=\text { static compliance } \\
\mathrm{R}_{\mathrm{N} \text { NS }} \mathrm{LSF}=\text { inspiratory resistances measured by least-square fit method } \\
\mathrm{RC}_{\mathrm{EXP}}=\text { expiratory time constant } \\
\mathrm{R}_{\mathrm{EXP}}=\text { expiratory resistance calculated from } \mathrm{RC}_{\mathrm{EXP}} \text { and } \mathrm{C}_{\mathrm{STAT}}\end{array}$} \\
\hline
\end{tabular}

Respiratory mechanics variables and ventilator settings were collected once per subject at the exact time of an arterial blood gas measurement. The time of data collection was chosen to be apart from nursing care and medical procedures.

Static compliance was calculated as the ratio between $\mathrm{V}_{\mathrm{T}}$ and driving pressure. Driving pressure was calculated as the difference between plateau pressure and total PEEP measured by a 5-s end-inspiratory and end-expiratory occlusion, respectively. ${ }^{20}$ Because subjects were ventilated in pressure control mode (with an exponential decay of inspiratory flow waveform), inspiratory resistance was measured by the least squares fitting method over the full respiratory cycle. ${ }^{21}$ The expiratory time constant was estimated by the $\mathrm{V}_{\mathrm{T}}$ /flow ratio at $75 \%$ of the expiratory $\mathrm{V}_{\mathrm{T}} \cdot{ }^{22}$

\section{Statistical Methods}

To perform subgroup analysis, the study was planned to stop after the inclusion of at least 100 normal lung subjects, 30 ARDS subjects for each severity subgroup, and 40 COPD subjects. Values are expressed as medians (in- terquartile range). Kruskal-Wallis analysis of variance was used to compare values between each type of lung conditions. Statistical significance was assumed for $P \leq .05$. Statistical analysis was performed using SigmaStat software 3.5 (SPSS, Chicago, Illinois).

\section{Results}

Among the 359 subjects included, 138 subjects were classified as normal lungs, 181 as ARDS, and 40 as COPD. Subjects' flow diagram and characteristics at inclusion are presented in Figure 1 and Table 1, respectively. Ventilator settings and arterial blood gas results are presented in Table 2.

Respiratory mechanics results are presented in Table 3 and Figure 2. Static compliance was significantly lower in ARDS subjects, as compared with normal lung and COPD subjects (39 [32-50] mL/cm $\mathrm{H}_{2} \mathrm{O}$ vs 54 [44-64] and 59 [43-75] $\mathrm{mL} / \mathrm{cm} \mathrm{H}_{2} \mathrm{O}$, respectively, $\left.P<.001\right)$. Inspiratory resistance was significantly higher in COPD subjects as compared with normal lung and ARDS subjects (22 [16-33] $\mathrm{cm} \mathrm{H}_{2} \mathrm{O} / \mathrm{L} / \mathrm{s}$ vs 13 [10-15] and 12 [9-14] cm 

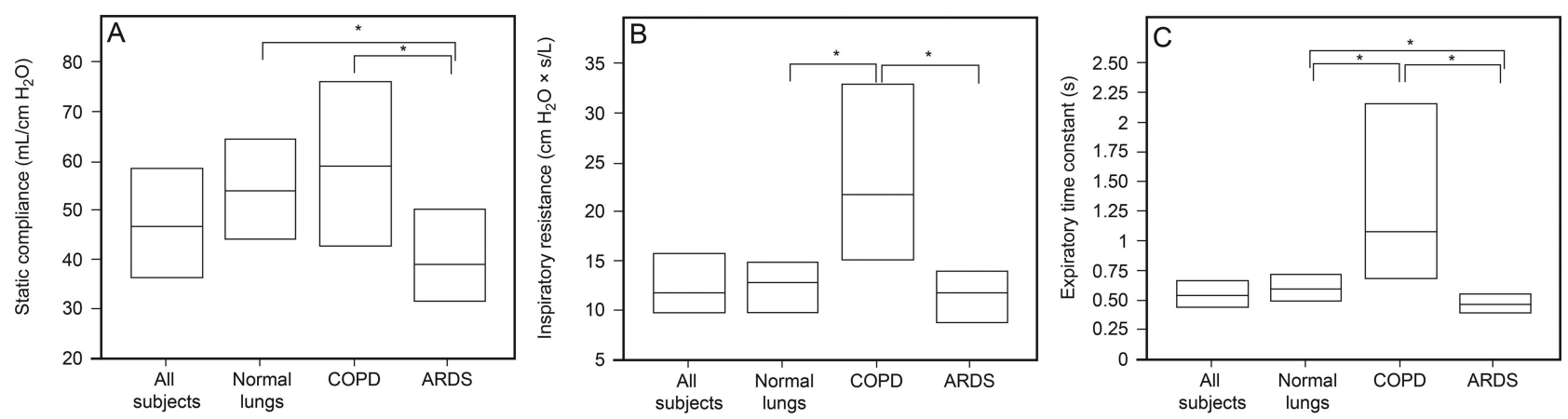

Fig. 2. Respiratory mechanics for all subjects and according to lung condition. Box plots represent median and interquartile range. ${ }^{*} P<.001$ for pairwise comparison using Dunn's method.

Table 4 Inspiratory Resistances According to Endotracheal Tube Size and Humidification

\begin{tabular}{|c|c|c|c|c|c|}
\hline Parameters & All Subjects & Normal Lungs & COPD & ARDS & $P$ \\
\hline \multicolumn{6}{|c|}{$\mathrm{R}_{\mathrm{INS}} \mathrm{LSF}$ with ETT $7.0, \mathrm{~cm} \mathrm{H}_{2} \mathrm{O} / \mathrm{L} / \mathrm{s}$} \\
\hline All & $14(13-16)$ & $14(13-15)$ & NA & $15(13-17)$ & \\
\hline $\mathrm{HH}$ & $14(13-16)$ & $13(13-14)$ & NA & $14(13-16)$ & \\
\hline HME & $16(13-19)$ & $15(13-18)$ & NA & $17(14-22)$ & \\
\hline \multicolumn{6}{|c|}{$\mathrm{R}_{\mathrm{INS}} \mathrm{LSF}$ with ETT $7.5, \mathrm{~cm} \mathrm{H}_{2} \mathrm{O} / \mathrm{L} / \mathrm{s}$} \\
\hline All & $13(11-16)$ & $13(11-15)$ & $27(18-39)$ & $12(10-14)$ & $<.001$ \\
\hline $\mathrm{HH}$ & $12(10-14)$ & $11(9-14)$ & $33(19-42)$ & $11(10-13)$ & $<.001$ \\
\hline HME & $15(12-16)$ & $14(12-16)$ & $26(16-29)$ & $14(12-17)$ & .02 \\
\hline \multicolumn{6}{|c|}{$\mathrm{R}_{\mathrm{INS}} \mathrm{LSF}$ with ETT $8.0, \mathrm{~cm} \mathrm{H}_{2} \mathrm{O} / \mathrm{L} / \mathrm{s}$} \\
\hline All & $11(9-14)$ & $11(10-13)$ & $18(12-23)$ & $10(8-13)$ & $<.001$ \\
\hline $\mathrm{HH}$ & $11(9-14)$ & $10(10-12)$ & $18(13-24)$ & $10(8-12)$ & $<.001$ \\
\hline HME & $13(11-14)$ & $13(11-14)$ & $16(12-20)$ & $14(10-17)$ & .63 \\
\hline $\begin{array}{l}\text { Results are median (interquartile } \\
\mathrm{R}_{\mathrm{INS}} \mathrm{LSF}=\text { inspiratory resistance } \\
\mathrm{ETT}=\text { endotracheal tube } \\
\mathrm{NA}=\text { not applicable } \\
\mathrm{HH}=\text { heated humidifier } \\
\mathrm{HME}=\text { heat and moisture exchan }\end{array}$ & $\begin{array}{l}\text { ysis of variance on } \\
\text { method }\end{array}$ & & & & \\
\hline
\end{tabular}

$\mathrm{H}_{2} \mathrm{O} / \mathrm{L} / \mathrm{s}$, respectively, $\left.P<.001\right)$. Inspiratory resistance according to the size of endotracheal tube and humidification system are presented in Table 4. Expiratory time constant was significantly different for each lung condition (0.60 [0.51-0.71], 1.07 [0.68-2.14], and 0.46 [0.40-0.55] s for normal lung, COPD, and ARDS subjects, respectively, $P<.001)$.

In the group of ARDS subjects, there were no significant differences in respiratory mechanics variables among mild, moderate, and severe ARDS subjects (Table 5 and Fig. 3).

\section{Discussion}

This study represents the largest single study describing respiratory system mechanical properties for all 3 populations commonly requiring mechanical ventilation in ICUs (ie, normal, COPD, and ARDS). As expected, all parameters show a large variation, yet median values per- mit distinction among patient populations and subpopulations (for ARDS) as shown in Tables 3 and 5. These median values are within the ranges of data reported in other studies for subjects with normal lungs, ${ }^{23-33}$ subjects with COPD, ${ }^{23-25,30,33,34}$ and subjects with ARDS (Tables 6-8). 23-28,30,35-61

The question, of course, is what to do with all of this information. One obvious application, and the primary purpose of this study, is to provide the basis of simulationbased medical education and research, particularly in the art and science of mechanical ventilation. ${ }^{62}$ Simulationbased medical education and simulation-based mastery learning have become well-established in undergraduate and graduate medical, nursing, and allied health-care training programs. ${ }^{63}$ Much like a standardized patient, ${ }^{64}$ a highfidelity lung simulator can provide the framework for teaching virtually any aspect of the physical interaction of a patient and a mechanical ventilator. Furthermore, a stan- 
Table 5 Respiratory Mechanics Results for the Subgroup of ARDS Subjects

\begin{tabular}{lccc}
\hline \hline \multicolumn{1}{c}{ Parameters } & Mild ARDS $(n=47)$ & Moderate ARDS $(n=95)$ & Severe ARDS $(n=39)$ \\
\hline $\mathrm{C}_{\mathrm{STAT}}, \mathrm{mL} / \mathrm{cm} \mathrm{H}_{2} \mathrm{O}$ & $44(36-53)$ & $39(31-49)$ & $38(30-45)$ \\
$\mathrm{R}_{\mathrm{INS}} \mathrm{LSF}, \mathrm{cm} \mathrm{H} \mathrm{H}_{2} \mathrm{O} / \mathrm{L} / \mathrm{s}$ & $11(9-14)$ & $12(10-14)$ & $12(9-14)$ \\
$\mathrm{RC}_{\mathrm{EXP}}, \mathrm{s}$ & $0.50(0.43-0.56)$ & $0.44(0.39-0.53)$ & $0.45(0.37-0.55)$ \\
$\mathrm{R}_{\mathrm{EXP}}, \mathrm{cm} \mathrm{H} \mathrm{H}_{2} \mathrm{O} / \mathrm{L} / \mathrm{s}$ & $13(10-15)$ & $14(11-16)$ & .74 \\
\end{tabular}

Results are median (interquartile range). $P$ values are from analysis of variance.

$\mathrm{C}_{\mathrm{STAT}}=$ static compliance

$\mathrm{R}_{\mathrm{INS}} \mathrm{LSF}=$ inspiratory resistance measured by least-square fit method

$\mathrm{RC}_{\mathrm{EXP}}=$ expiratory time constant

$\mathrm{R}_{\mathrm{EXP}}=$ expiratory resistances calculated from $\mathrm{RC}_{\mathrm{EXP}}$ and $\mathrm{C}_{\mathrm{STAT}}$
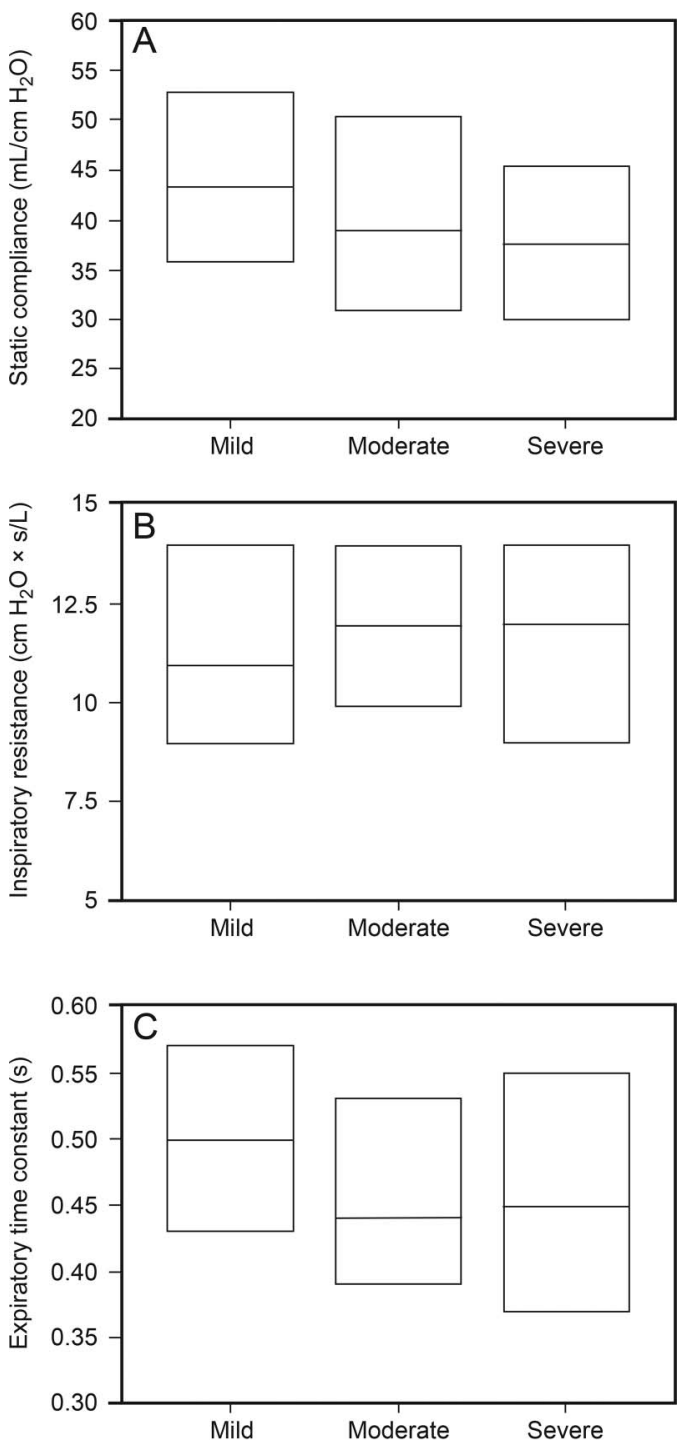

Fig. 3. Respiratory mechanics for ARDS subjects and according to severity: Box plots represent median and interquartile range.

dard set of simulation parameters would provide researchers with a common basis for conducting ventilator performance studies. Manufacturers of ventilators could also use this information for conducting realistic new product verification and validation studies.

\section{Standard Simulation Parameters}

A convenient theoretical basis for standardizing simulation parameters is a mathematical model of respiratory system mechanics. The simplest model of the respiratory system used for ventilator studies is the single-compartment model, composed of a single flow resistance and a single elastic compartment, represented by the equation of motion for the respiratory system, ${ }^{65,66}$

$$
\mathrm{P}_{\text {vent }}(\mathrm{t})+\mathrm{P}_{\text {mus }}(\mathrm{t})-\text { auto-PEEP }=\mathrm{EV}(\mathrm{t})+\mathrm{RV}(\mathrm{t})
$$

where the following are true. $\mathrm{P}_{\text {vent }}(\mathrm{t})=$ the change in transrespiratory pressure difference (ie, airway opening pressure minus body surface pressure) as a function of time (t), measured relative to end-expiratory airway pressure. This is the pressure generated by a ventilator during an assisted breath. $\mathrm{P}_{\text {mus }}(\mathrm{t})=$ ventilatory muscle pressure difference as a function of time $(\mathrm{t})$; the theoretical chest wall transmural pressure difference that would produce movements identical to those produced by the ventilatory muscles during breathing maneuvers (positive during inspiratory effort, negative during expiratory effort). $\mathrm{V}(\mathrm{t})=$ volume change relative to end-expiratory volume as a function of time $(t) \cdot \dot{V}(t)=$ flow as a function of time $(t)$, the first derivative of volume with respect to time. $\mathrm{E}=$ elastance (inverse of compliance; $\mathrm{E}=1 / \mathrm{C}$ ). $\mathrm{R}=$ resistance. auto-PEEP $=$ end-expiratory alveolar pressure above end-expiratory airway pressure.

In this equation, pressure, volume, and flow are variables, whereas elastance and resistance are parameters (assumed to be constants). This happens to be the same model used by ventilators that calculate and display resistance and compliance values of patients. Indeed, the graphic waveforms for pressure, volume, and flow displayed by such ventilators are nothing other than the graphical representation of the equation of motion. The compliance (C) of the model is generally 
Simulation of Adult Subjects During Mechanical Ventilation

Table 6 Respiratory Mechanics Results From Other Studies for Normal Subjects

\begin{tabular}{|c|c|c|c|c|c|c|c|c|}
\hline Study & Year & Subjects, $N$ & Method & $\mathrm{C}^{*}$ & $\mathrm{R}_{\mathrm{INS}}^{\dagger}{ }^{\dagger}$ & $\mathrm{RC}_{\mathrm{EXP}}{ }^{\dagger}$ & $\mathrm{R}_{\mathrm{EXP}} \S$ & Definition of Normal \\
\hline Arnal $^{23}$ & 2008 & 115 & LSF/75\% expiration & 40 & 16 & 0.78 & 20 & Yes \\
\hline Arnal $^{24}$ & 2013 & 27 & LSF/75\% expiration & 39 & 15 & 0.58 & 15 & No \\
\hline Arnal (unpublished) & 2015 & 20 & LSF/75\% expiration & 51 & 14 & 0.65 & 13 & No \\
\hline Belliato $^{25}$ & 2004 & 8 & LSF/75\% expiration & 49 & 12 & 0.72 & 15 & No \\
\hline Chang ${ }^{26}$ & 2013 & 722 & Conventional & 39 & NR & NR & NR & No \\
\hline Chiumello $^{27}$ & 2008 & 19 & Conventional & 56 & NR & NR & NR & No \\
\hline Fretschner $^{28}$ & 1996 & 10 & LSF/75\% expiration & 56 & NR & NR & NR & No \\
\hline Futier $^{29}$ & 2013 & 400 & Conventional & 53 & NR & NR & NR & No \\
\hline Iotti $^{30}$ & 2010 & 22 & LSF/75\% expiration & 51 & 13 & 0.71 & 14 & No \\
\hline $\mathrm{Jia}^{31}$ & 2008 & 636 & Conventional & 46 & NR & NR & NR & No \\
\hline Koutsoukou $^{32}$ & 2006 & 21 & Conventional & NR & 10 & NR & NR & No \\
\hline Volta $^{33}$ & 2002 & 8 & Conventional & NR & 12 & NR & NR & No \\
\hline $\begin{array}{l}\text { * Median }=50 ; \text { maximum } \\
\dagger \text { Median }=13 ; \text { maximum } \\
\ddagger \text { Median }=0.7 ; \text { maximum } \\
\S \text { Median }=15 ; \text { maximum } \\
C=\text { compliance } \\
\mathrm{R}_{\mathrm{INS}}=\text { inspiratory resistanc } \\
\mathrm{RC}_{\mathrm{EXP}}=\text { expiratory time } c \\
\mathrm{R}_{\mathrm{EXP}}=\text { expiratory resistanc } \\
\mathrm{LSF}=\text { least-square fit meth } \\
\mathrm{NR}=\text { not reported }\end{array}$ & $\begin{array}{l}\text { minimum } \\
\text { minimum } \\
\text {; minimu } \\
\text { minimum }\end{array}$ & $\mathrm{C}_{\mathrm{EXP}}$ and $\mathrm{C}$ & & & & & & \\
\hline
\end{tabular}

Table 7 Respiratory Mechanics Results From Other Studies for Subjects With COPD

\begin{tabular}{|c|c|c|c|c|c|c|c|c|}
\hline Study & Year & Subjects, $N$ & Method & $\mathrm{C}^{*}$ & $\mathrm{R}_{\mathrm{INS}} \dagger$ & $\mathrm{RC}_{\mathrm{EXP}} \dagger$ & $\mathrm{R}_{\mathrm{EXP}} \S$ & Definition of COPD \\
\hline $\mathrm{Arnal}^{23}$ & 2008 & 33 & LSF/75\% expiration & 48 & 21 & 1.00 & 21 & GOLD \\
\hline $\mathrm{Arnal}^{24}$ & 2013 & 12 & LSF/75\% expiration & 53 & 21 & 1.22 & 23 & GOLD \\
\hline Arnal (unpublished) & 2015 & 9 & LSF/75\% expiration & 58 & 23 & 1.13 & 19 & GOLD \\
\hline Belliato $^{25}$ & 2004 & 8 & LSF/75\% expiration & 65 & 25 & 2.21 & 34 & ATS \\
\hline Iotti $^{30}$ & 2010 & 30 & LSF/75\% expiration & 55 & 20 & 1.08 & 20 & No \\
\hline Lourens $^{34}$ & 2000 & 8 & $75 \%$ expiration & NR & NR & 1.05 & NR & Moderate COPD \\
\hline Lourens $^{34}$ & 2000 & 18 & $75 \%$ expiration & NR & NR & 2.84 & NR & Severe COPD \\
\hline Volta ${ }^{33}$ & 2002 & 8 & Conventional & NR & 20 & NR & NR & No \\
\hline $\begin{array}{l}\text { * Median }=55 ; \text { maximum }= \\
\dagger \text { Median }=21 ; \text { maximum }= \\
\ddagger \text { Median }=1.1 ; \text { maximum } \\
\S \text { Median }=21 ; \text { maximum }= \\
\mathrm{C}=\text { compliance } \\
\mathrm{R}_{\mathrm{INS}}=\text { inspiratory resistance } \\
\mathrm{RC}_{\mathrm{EXP}}=\text { expiratory time co } \\
\mathrm{R}_{\mathrm{EXP}}=\text { expiratory resistance } \\
\mathrm{LSF}=\text { least-square fit meth } \\
\mathrm{GOLD}=\text { Global Initiative } \\
\mathrm{ATS}=\text { American Thoracic } \\
\mathrm{NR}=\text { not reported }\end{array}$ & $\begin{array}{l}\text { minimum } \\
\text { minimum } \\
\text {; minimu } \\
\text { minimum } \\
\text { ulated fro } \\
\text { ronic Ob } \\
\text { ty }\end{array}$ & $\begin{array}{l}\mathrm{C}_{\mathrm{EXP}} \text { and } \mathrm{C} \\
\text { ive Lung Disease }\end{array}$ & & & & & & \\
\hline
\end{tabular}

assumed to be linear for ventilator performance studies, in the form of $\mathrm{C}=\Delta$ volume/ $\Delta$ pressure. The resistance $(\mathrm{R})$ is modeled as either linear $(\mathrm{R}=\Delta$ pressure/ $\Delta$ flow) or non-linear (eg, parabolic). A parabolic resistor is one for which pressure is proportional to the square of flow. Note that for a parabolic resistor, the resistance is often defined as $\Delta$ pressure/ $\Delta$ flow at a particular flow value. This means that the equivalent linear resistance is different for each flow at which it is evaluated.
In other words, using a parabolic resistor, the resistive load of the lung model changes as flow changes. Hence, to maintain consistent testing parameters across different flows, it is usually better to select linear rather than parabolic resistors for ventilator performance evaluation studies.

To our knowledge, this study is the first attempt to provide standardized, evidence-based simulation parameters for the mechanical properties of the adult human re- 
Simulation of Adult Subjects During Mechanical Ventilation

Table 8 Respiratory Mechanics Results From Other Studies for Subjects With ARDS

\begin{tabular}{|c|c|c|c|c|c|c|c|c|}
\hline First Author & Year & Subjects, $N$ & Method & $\mathrm{C}^{*}$ & $\mathrm{R}_{\mathrm{INS}} \dagger$ & $\mathrm{RC}_{\mathrm{EXP}} \ddagger$ & $\mathrm{R}_{\mathrm{EXP}} \S$ & Definition of ARDS \\
\hline Amato $^{35}$ & 1998 & 53 & Conventional & 29 & NR & NR & NR & \\
\hline Brower $^{36}$ & 2004 & 474 & Conventional & 35 & NR & NR & NR & AECC \\
\hline $\operatorname{Arnal}^{23}$ & 2008 & 26 & LSF/75\% expiration & 27 & 15 & 0.51 & 19 & AECC \\
\hline Arnal $^{24}$ & 2013 & 13 & LSF/75\% expiration & 29 & 11 & 0.47 & 16 & AECC \\
\hline $\operatorname{Arnal}^{37}$ & 2011 & 50 & LSF/75\% expiration & 30 & NR & NR & NR & AECC \\
\hline $\operatorname{Arnal}^{38}$ & 2012 & 31 & LSF/75\% expiration & 35 & 16 & NR & NR & AECC \\
\hline Belliato $^{25}$ & 2004 & 5 & LSF/75\% expiration & 26 & 13 & 0.47 & 18 & AECC \\
\hline Brower $^{39}$ & 2003 & 96 & Conventional & 35 & NR & NR & NR & AECC \\
\hline Caironi ${ }^{40}$ & 2010 & 68 & Conventional & 43 & NR & NR & NR & AECC \\
\hline Chang 26 & 2013 & 107 & Conventional & 32 & NR & NR & NR & AECC \\
\hline Chiumello27 & 2008 & 24 & Conventional & 42 & NR & NR & NR & AECC \\
\hline Chiumello $^{41}$ & 2013 & 51 & Conventional & 37 & NR & NR & NR & AECC \\
\hline Chiumello $^{42}$ & 2013 & 44 & Conventional & 42 & NR & NR & NR & Berlin \\
\hline Cressoni ${ }^{43}$ & 2014 & 148 & Conventional & 43 & NR & NR & NR & Berlin \\
\hline Dellamonica $^{44}$ & 2011 & 30 & Conventional & 31 & NR & NR & NR & AECC \\
\hline Dellamonica $^{45}$ & 2013 & 40 & Conventional & 36 & NR & NR & NR & AECC \\
\hline Demory ${ }^{46}$ & 2008 & 26 & LSF/75\% expiration & 32 & NR & NR & NR & AECC \\
\hline Estenssoro ${ }^{47}$ & 2003 & 48 & Conventional & 26 & NR & NR & NR & AECC \\
\hline Galiatsou $^{48}$ & 2006 & 21 & Conventional & 30 & NR & NR & NR & AECC \\
\hline Gattinoni ${ }^{49}$ & 2006 & 68 & Conventional & 44 & NR & NR & NR & AECC \\
\hline Iotti $^{30}$ & 2010 & 36 & LSF/75\% expiration & 34 & 15 & 0.5 & 15 & AECC \\
\hline Mercat $^{50}$ & 2008 & 767 & Conventional & 36 & NR & NR & NR & AECC \\
\hline Morán ${ }^{51}$ & 2011 & 13 & Conventional & 28 & NR & NR & NR & AECC \\
\hline Nuckton $^{52}$ & 2002 & 179 & Conventional & 30 & NR & NR & NR & AECC \\
\hline Oczenski $^{53}$ & 2004 & 30 & Conventional & 35 & NR & NR & NR & AECC \\
\hline Osman $^{54}$ & 2009 & 145 & Conventional & 32 & NR & NR & NR & AECC \\
\hline Papazian 55 & 2010 & 339 & Conventional & 31 & NR & NR & NR & AECC \\
\hline Talmor $^{56}$ & 2008 & 61 & Conventional & 36 & NR & NR & NR & AECC \\
\hline Terragni ${ }^{57}$ & 2007 & 30 & Conventional & 26 & NR & NR & NR & AECC \\
\hline Thille 58 & 2007 & 71 & Conventional & 35 & NR & NR & NR & AECC \\
\hline Villagrá59 & 2002 & 17 & Conventional & 33 & NR & NR & NR & AECC \\
\hline Villar60 & 2007 & 170 & Conventional & 32 & NR & NR & NR & AECC \\
\hline Wallet $^{61}$ & 2013 & 14 & Conventional & 44 & NR & NR & NR & AECC \\
\hline \multicolumn{9}{|c|}{$\begin{array}{l}\text { * Median }=33 ; \text { maximum }=44 ; \text { minimum }=26 . \\
\dagger \text { Median }=15 ; \text { maximum }=16 ; \text { minimum }=11 . \\
\ddagger \text { Median }=0.5 ; \text { maximum }=0.5 ; \text { minimum }=0.5 . \\
\S \text { Median }=17 ; \text { maximum }=19 ; \text { minimum }=15 . \\
C=\text { compliance } \\
\mathrm{R}_{\mathrm{INS}}=\text { inspiratory resistance } \\
\mathrm{RC}_{\mathrm{EXP}}=\text { expiratory time constant } \\
\mathrm{R}_{\mathrm{EXP}}=\text { expiratory resistance calculated from } \mathrm{RC}_{\mathrm{EXP}} \text { and } \mathrm{C} \\
\mathrm{LSF}=\text { least-square fit method } \\
\mathrm{AECC}=\text { American-European consensus conference } \\
\mathrm{NR}=\text { not reported }\end{array}$} \\
\hline
\end{tabular}

spiratory system linked to realistic, general mechanical ventilator settings and patient demographics. In creating our recommendations, we necessarily must summarize and simplify the data at hand. Hence, we have condensed the information from the previous tables in Table 9. We have also simplified it by rounding values to whole numbers for convenience while maintaining the general magnitude of the parameter within realistic ranges, as indicated by our study and those of others. Obviously, we could have selected other values, but these seem to be reasonable, within the specifications of available mechanical simulators, and perhaps also fairly easily manufactured from scratch (eg, rubber test lungs with variable resistance and compliance settings or rigid walled lung models). ${ }^{67}$

Our study is limited by the fact that it was conducted at a single institution with a single mode of ventilation. To the extent that a mode of ventilation and a particular style of clinical management (including selection of optimum PEEP levels) can influence the mechanical properties of various populations of patients, our data are biased. How- 
Table 9 Standardized Parameters for Simulation of Mechanical Ventilation in the Adult

\begin{tabular}{|c|c|c|c|c|c|c|}
\hline \multirow{2}{*}{ Parameters } & \multirow{2}{*}{ Normal } & \multirow{2}{*}{ COPD } & \multicolumn{4}{|c|}{ ARDS } \\
\hline & & & All & Mild & Moderate & Severe \\
\hline $\mathrm{C}_{\mathrm{STAT}}, \mathrm{mL} / \mathrm{cm} \mathrm{H}_{2} \mathrm{O}$ & 50 & 60 & 40 & 45 & 40 & 35 \\
\hline $\mathrm{HH}-\mathrm{R}_{\mathrm{INS}}, \mathrm{cm} \mathrm{H}_{2} \mathrm{O} / \mathrm{L} / \mathrm{s}$ & 10 & 20 & 10 & 10 & 10 & 10 \\
\hline $\mathrm{HH}-\mathrm{RC}, \mathrm{s}$ & 0.50 & 1.20 & 0.35 & 0.45 & 0.35 & 0.25 \\
\hline $\mathrm{HME}-\mathrm{R}_{\mathrm{INS}}, \mathrm{cm} \mathrm{H}_{2} \mathrm{O} / \mathrm{L} / \mathrm{s}$ & 15 & 25 & 15 & 15 & 15 & 15 \\
\hline HME - RC, s & 0.75 & 1.50 & 0.53 & 0.68 & 0.53 & 0.38 \\
\hline $\begin{array}{l}\mathrm{C}_{\mathrm{STAT}}=\text { static compliance } \\
\mathrm{HH}=\text { heated humidifier } \\
\mathrm{R}_{\mathrm{INS}}=\text { inspiratory resistance } \\
\mathrm{HME}=\text { heat-and-moisture exc } \\
\mathrm{RC}=\text { time constant }\end{array}$ & anger & & & & & \\
\hline
\end{tabular}

ever, the bias may be trivial, given the favorable comparison of our median values with those of a vast number of previous studies. Furthermore, our data are not intended to be optimal or even benchmark values for actual patient care. Another limitation is that all measurements were performed in passively ventilated subjects. Respiratory mechanics variables (ie, resistance and compliance) are the same in passively and actively breathing patients during assisted ventilation, other factors being essentially equal (eg, $\mathrm{V}_{\mathrm{T}}$ and flow). The main problem with simulation of the spontaneously breathing patient is the effort model parameters (ie, $\mathrm{P}_{\text {mus }}$ waveform characteristics).

\section{Conclusions}

Effort model parameters are difficult to evaluate during mechanical ventilation with the current technology, and they have a lot of variability. However, having reasonable values for passive mechanics (such as the results of our study), future researchers may then impose any effort model parameters they can imagine for the intended simulation study. In conclusion, this study provides educators, researchers, and manufacturers with a standard set of practical, evidence-based parameters for simulating the respiratory system's mechanical properties under passive conditions.

\section{REFERENCES}

1. Chatburn RL. Simulation studies for device evaluation. Respir Care 2014;59(4):e61-e66.

2. Blakeman TC, Branson RD. Evaluation of 4 new generation portable ventilators. Respir Care 2013;58(2):264-272.

3. Wallon G, Bonnet A, Guérin C. Delivery of tidal volume from four anaesthesia ventilators during volume-controlled ventilation: a bench study. Br J Anaesth 2013;110(6):1045-1051.

4. Blakeman TC, Rodriquez D Jr, Hanseman D, Branson RD. Bench evaluation of 7 home-care ventilators. Respir Care 2011;56(11):17911798 .
5. Garnier M, Quesnel C, Fulgencio JP, Degrain M, Carteaux G, Bonnet $\mathrm{F}$, et al. Multifaceted bench comparative evaluation of latest intensive care unit ventilators. Br J Anaesth 2015;115(1):89-98.

6. Chatburn RL, Mireles-Cabodevila E, Sasidhar M. Tidal volume measurement error in pressure control modes of mechanical ventilation: A model study. Comput Biol Med 2016;75:235-242.

7. Vasconcelos RS, Sales RP, Melo LHP, Marinho LS, Bastos VP, Nogueira ADN, et al. Influences of duration of inspiratory effort, respiratory mechanics, and ventilator type on asynchrony with pressure support and proportional assist ventilation. Respir Care 2017; 62(5):550-557.

8. Itagaki T, Chenelle CT, Bennett DJ, Fisher DF, Kacmarek RM. Effects of leak compensation on patient-ventilator synchrony during premature/neonatal invasive and noninvasive ventilation: a lung model study. Respir Care 2017;62(1):22-33.

9. Itagaki T, Bennett DJ, Chenelle CT, Fisher DF, Kacmarek RM. Performance of leak compensation in all-age ICU ventilators during volume-targeted neonatal ventilation: a lung model study. Respir Care 2017;62(1):10-21.

10. Vasconcelos Rdos S, Melo LH, Sales RP, Marinho LS, Deulefeu FC, Reis RC, et al. Effect of an automatic triggering and cycling system on comfort and patient-ventilator synchrony during pressure support ventilation. Respiration 2013;86(6):497-503.

11. Volsko TA, Hoffman J, Conger A, Chatburn RL. The effect of targeting scheme on tidal volume delivery during volume control mechanical ventilation. Respir Care 2012;57(8):1297-1304.

12. Mireles-Cabodevila E, Chatburn RL. Work of breathing in adaptive pressure control continuous mandatory ventilation. Respir Care 2009; 54(11):1467-1472.

13. Terado M, Ichiba S, Nagano O, Ujike Y. Evaluation of pressure support ventilation with seven different ventilators using Active Servo Lung 5000. Acta Med Okayama 2008;62(2):127-133.

14. Chen Y, Cheng K, Zhou X. Performance characteristics of seven bilevel mechanical ventilators in pressure-support mode with different cycling criteria: a comparative bench study. Med Sci Monit 2015;21:310-317

15. Chen Y, Cheng K, Zhou X. Effectiveness of inspiratory termination synchrony with automatic cycling during noninvasive pressure support ventilation. Med Sci Monit 2016;22:1694-1701.

16. Ferguson ND, Fan E, Camporota L, Antonelli M, Anzueto A, Beale $\mathrm{R}$, et al. The Berlin definition of ARDS: an expanded rationale, justification, and supplementary material. Intensive Care Med 2012; 38(10):1573-1582.

17. Vestbo J, Hurd SS, Agustí AG, Jones PW, Vogelmeier C, Anzueto A, et al. Global strategy for the diagnosis, management, and prevention of chronic obstructive pulmonary disease: GOLD executive summary. Am J Respir Crit Care Med 2013;187(4):347-365.

18. Chatburn RL, El-Khatib M, Mireles-Cabodevila E. A taxonomy for mechanical ventilation: 10 fundamental maxims. Respir Care 2014; 59(11):1747-1763.

19. Acute Respiratory Distress Syndrome Network, Brower RG, Matthay MA, Morris A, Schoenfeld D, Thompson BT, Wheeler A. Ventilation with lower tidal volumes as compared with traditional tidal volumes for acute lung injury and the acute respiratory distress syndrome. N Engl J Med 2000;342(18):1301-1308.

20. Lucangelo U, Bernabè F, Blanch L. Lung mechanics at the bedside: make it simple. Curr Opin Crit Care 2007;13(1):64-72.

21. Iotti GA, Braschi A, Brunner JX, Smits T, Olivei M, Palo A, Veronesi R. Respiratory mechanics by least squares fitting in mechanically ventilated patients: applications during paralysis and during pressure support ventilation. Intensive Care Med 1995;21(5):406413.

22. Brunner JX, Laubscher TP, Banner MJ, Iotti G, Braschi A. Simple method to measure total expiratory time constant based on the pas- 


\section{Simulation of Adult Subjects During Mechanical Ventilation}

sive expiratory flow-volume curve. Crit Care Med 1995;23(6):11171122.

23. Arnal JM, Wysocki M, Nafati C, Donati S, Granier I, Corno G, Durand-Gasselin J. Automatic selection of breathing pattern using adaptive support ventilation. Intensive Care Med 2008;34(1):75-81.

24. Arnal JM, Garnero A, Novonti D, Demory D, Ducros L, Berric A, et al. Feasibility study on full closed-loop control ventilation (IntelliVent-ASV) in ICU patients with acute respiratory failure: a prospective observational comparative study. Crit Care 2013;17(5):R196.

25. Belliato M, Palo A, Pasero D, Iotti GA, Mojoli F, Braschi A. Evaluation of adaptive support ventilation in paralysed patients and in a physical lung model. Int J Artif Organs 2004;27(8):709-716.

26. Chang SY, Dabbagh O, Gajic O, Patrawalla A, Elie MC, Talmor DS, et al. Contemporary ventilator management in patients with and at risk of ALI/ARDS. Respir Care 2013;58(4):578-588.

27. Chiumello D, Carlesso E, Cadringher P, Caironi P, Valenza F, Polli $\mathrm{F}$, et al. Lung stress and strain during mechanical ventilation for acute respiratory distress syndrome. Am J Respir Crit Care Med 2008;178(4):346-355.

28. Fretschner R, Laubscher TP, Brunner JX. New aspects of pulmonary mechanics: "slowly" distensible compartments of the respiratory system, identified by a PEEP step maneuver. Intensive Care Med 1996; 22(12):1328-1334.

29. Futier E, Constantin JM, Paugam-Burtz C, Pascal J, Eurin M, Neuschwander A, et al. A trial of intraoperative low-tidal-volume ventilation in abdominal surgery. N Engl J Med 2013;369(5):428-437.

30. Iotti GA, Polito A, Belliato M, Pasero D, Beduneau G, Wysocki M, et al. Adaptive support ventilation versus conventional ventilation for total ventilatory support in acute respiratory failure. Intensive Care Med 2010;36(8):1371-1379.

31. Jia X, Malhotra A, Saeed M, Mark RG, Talmor D. Risk factors for ARDS in patients receiving mechanical ventilation for $>48 \mathrm{~h}$. Chest 2008;133(4):853-861.

32. Koutsoukou A, Perraki H, Raftopoulou A, Koulouris N, Sotiropoulou C, Kotanidou A, et al. Respiratory mechanics in brain-damaged patients. Intensive Care Med 2006;32(12):1947-1954.

33. Volta CA, Marangoni E, Alvisi V, Capuzzo M, Ragazzi R, Pavanelli L, Alvisi R. Respiratory mechanics by least squares fitting in mechanically ventilated patients: application on flow-limited COPD patients. Intensive Care Med 2002;28(1):48-52.

34. Lourens MS, van den Berg B, Aerts JG, Verbraak AF, Hoogsteden HC, Bogaard JM. Expiratory time constants in mechanically ventilated patients with and without COPD. Intensive Care Med 2000; 26(11):1612-1618.

35. Amato MB, Barbas CS, Medeiros DM, Magaldi RB, Schettino GP, Lorenzi-Filho G, et al. Effect of a protective-ventilation strategy on mortality in the acute respiratory distress syndrome. N Engl J Med 1998;338(6):347-354

36. Brower RG, Lanken PN, MacIntyre N, Matthay MA, Morris A, Ancukiewicz M, et al. Higher versus lower positive end-expiratory pressures in patients with the acute respiratory distress syndrome. N Engl J Med 2004;351(4):327-336.

37. Arnal JM, Paquet J, Wysocki M, Demory D, Donati S, Granier I, et al. Optimal duration of a sustained inflation recruitment maneuver in ARDS patients. Intensive Care Med 2011;37(10):1588-1594.

38. Arnal JM, Wysocki M, Novotni D, Demory D, Lopez R, Donati S, et al. Safety and efficacy of a fully closed-loop control ventilation (IntelliVent-ASV(R)) in sedated ICU patients with acute respiratory failure: a prospective randomized crossover study. Intensive Care Med 2012;38(5):781-787.

39. Brower RG, Morris A, MacIntyre N, Matthay MA, Hayden D, Thompson $\mathrm{T}$, et al. Effects of recruitment maneuvers in patients with acute lung injury and acute respiratory distress syndrome ventilated with high positive end-expiratory pressure. Crit Care Med 2003;31(11): 2592-2597.

40. Caironi P, Cressoni M, Chiumello D, Ranieri M, Quintel M, Russo SG, et al. Lung opening and closing during ventilation of acute respiratory distress syndrome. Am J Respir Crit Care Med 2010; 181(6):578-586.

41. Chiumello D, Marino A, Cressoni M, Mietto C, Berto V, Gallazzi E, et al. Pleural effusion in patients with acute lung injury: a CT scan study. Crit Care Med 2013;41(4):935-944.

42. Chiumello D, Coppola S, Froio S, Mietto C, Brazzi L, Carlesso E, Gattinoni L. Time to reach a new steady state after changes of positive end expiratory pressure. Intensive Care Med 2013;39(8): 1377-1385.

43. Cressoni M, Cadringher P, Chiurazzi C, Amini M, Gallazzi E, Marino $\mathrm{A}$, et al. Lung inhomogeneity in patients with acute respiratory distress syndrome. Am J Respir Crit Care Med 2014;189(2):149158.

44. Dellamonica J, Lerolle N, Sargentini C, Beduneau G, Di Marco F, Mercat A, et al. PEEP-induced changes in lung volume in acute respiratory distress syndrome: two methods to estimate alveolar recruitment. Intensive Care Med 2011;37(10):1595-1604.

45. Dellamonica J, Lerolle N, Sargentini C, Hubert S, Beduneau G, Di Marco F, et al. Effect of different seated positions on lung volume and oxygenation in acute respiratory distress syndrome. Intensive Care Med 2013;39(6):1121-1127

46. Demory D, Arnal JM, Wysocki M, Donati S, Granier I, Corno G, Durand-Gasselin J. Recruitability of the lung estimated by the pressure volume curve hysteresis in ARDS patients. Intensive Care Med 2008;34(11):2019-2025.

47. Estenssoro E, Dubin A, Laffaire E, Canales HS, Sáenz G, Moseinco $\mathrm{M}$, Bachetti P. Impact of positive end-expiratory pressure on the definition of acute respiratory distress syndrome. Intensive Care Med 2003;29(11):1936-1942.

48. Galiatsou E, Kostanti E, Svarna E, Kitsakos A, Koulouras V, Efremidis SC, Nakos G. Prone position augments recruitment and prevents alveolar overinflation in acute lung injury. Am J Respir Crit Care Med 2006;174(2):187-197.

49. Gattinoni L, Caironi P, Cressoni M, Chiumello D, Ranieri VM, Quintel M, et al. Lung recruitment in patients with the acute respiratory distress syndrome. N Engl J Med 2006;354(17):1775-1786.

50. Mercat A, Richard JC, Vielle B, Jaber S, Osman D, Diehl JL, et al. Positive end-expiratory pressure setting in adults with acute lung injury and acute respiratory distress syndrome: a randomized controlled trial. JAMA 2008;299(6):646-655.

51. Morán I, Blanch L, Fernández R, Fernández-Mondéjar E, Zavala E, Mancebo J. Acute physiologic effects of a stepwise recruitment maneuver in acute respiratory distress syndrome. Minerva Anestesiol 2011;77(12):1167-1175

52. Nuckton TJ, Alonso JA, Kallet RH, Daniel BM, Pittet JF, Eisner MD, Matthay MA. Pulmonary dead-space fraction as a risk factor for death in the acute respiratory distress syndrome. N Engl J Med 2002;346(17):1281-1286.

53. Oczenski W, Hörmann C, Keller C, Lorenzl N, Kepka A, Schwarz S, Fitzgerald RD. Recruitment maneuvers after a positive end-expiratory pressure trial do not induce sustained effects in early adult respiratory distress syndrome. Anesthesiology 2004;101(3):620-625.

54. Osman D, Monnet X, Castelain V, Anguel N, Warszawski J, Teboul $\mathrm{JL}$, et al. Incidence and prognostic value of right ventricular failure in acute respiratory distress syndrome. Intensive Care Med 2009; 35(1):69-76.

55. Papazian L, Forel JM, Gacouin A, Penot-Ragon C, Perrin G, Loundou A, et al. Neuromuscular blockers in early acute respiratory distress syndrome. N Engl J Med 2010;363(12):1107-1116. 


\section{Simulation of Adult Subjects During Mechanical Ventilation}

56. Talmor D, Sarge T, Malhotra A, O’Donnell CR, Ritz R, Lisbon A, et al. Mechanical ventilation guided by esophageal pressure in acute lung injury. N Engl J Med 2008;359(20):2095-2104.

57. Terragni PP, Rosboch G, Tealdi A, Corno E, Menaldo E, Davini O, et al. Tidal hyperinflation during low tidal volume ventilation in acute respiratory distress syndrome. Am J Respir Crit Care Med 2007;175(2):160-166.

58. Thille AW, Richard JC, Maggiore SM, Ranieri VM, Brochard L. Alveolar recruitment in pulmonary and extrapulmonary acute respiratory distress syndrome: comparison using pressure-volume curve or static compliance. Anesthesiology 2007;106(2):212-217.

59. Villagrá A, Ochagavía A, Vatua S, Murias G, Del Mar Fernández M, Lopez Aguilar J, et al. Recruitment maneuvers during lung protective ventilation in acute respiratory distress syndrome. Am J Respir Crit Care Med 2002;165(2):165-170.

60. Villar J, Pérez-Méndez L, López J, Belda J, Blanco J, Saralegui I, et al. An early PEEP/ $/ \mathrm{F}_{2}$ trial identifies different degrees of lung injury in patients with acute respiratory distress syndrome. Am J Respir Crit Care Med 2007;176(8):795-804.
61. Wallet F, Delannoy B, Haquin A, Debord S, Leray V, Bourdin G, et al. Evaluation of recruited lung volume at inspiratory plateau pressure with PEEP using bedside digital chest X-ray in patients with acute lung injury/ARDS. Respir Care 2013;58(3):416-423.

62. Yee J, Fuenning C, George R, Hejal R, Haines N, Dunn D, et al. Mechanical ventilation boot camp: a simulation-based pilot study. Crit Care Res Pract 2016;2016:4670672.

63. Okla G, Eden D, Okla N. Simulation lab: "a contemporary medical essential”. Middle East J Anaesthesiol 2016;23(4):501-503.

64. Adamo G. Simulated and standardized patients in OSCEs: achievements and challenges 1992-2003. Med Teach 2003;25(3):262-270.

65. Henderson WR, Chen L, Amato MB, Brochard LJ. Fifty years of research in ARDS: respiratory mechanics in acute respiratory distress syndrome. Am J Respir Crit Care Med 2017;196(7):822-833.

66. Primiano FP Jr., Chatburn RL. Zen and the art of nomenclature maintenance: a revised approach to respiratory symbols and terminology. Respir Care 2006;51(12):1458-1470.

67. Hill DW, Moore V. The action of adiabatic effects on the compliance of an artificial thorax. Br J Anaesth 1965;37:19-22.

This article is approved for Continuing Respiratory Care Education credit. For information and to obtain your CRCE

(free to AARC members) visit

www.rcjournal.com 